\title{
Regenerative Medicine Venturing at the University-Industry Boundary: Implications for Institutions, Entrepreneurs, and Industry
}

\author{
Adam J. Bock \\ University of Wisconsin-Madison \\ David Johnson \\ Edinburgh Napier University Business School
}

\begin{abstract}
Regenerative medicine research at university laboratories has outpaced commercial activity. Legal, regulatory, funding, technological and operational uncertainty have slowed market entry of regenerative medicine treatments. As a result, commercial development has often been led by entrepreneurial ventures rather than large biopharma firms. Translating regenerative medicine across the university-industry boundary links academic scientists, technology transfer organizations, funders, and entrepreneurs. Conflicting motivations among the participants may significantly hinder these efforts. Unproven downstream business models for regenerative medicine delivery further complicates the entrepreneurial process. This chapter explores the challenges associated with entrepreneurial activity commercializing regenerative medicine science developed at research institutions.
\end{abstract}

Keywords: commercialization, entrepreneurship, technology transfer, venturing, regenerative medicine 


\subsection{Introduction}

Regenerative medicine is cutting edge science and potentially big business. Billions of dollars are being invested in research and development and infrastructure amidst shifting government policies, complex lawsuits, uncertain regulatory and pricing policies, and capitalintensive market entry requirements. Long-term estimates for the market value of regenerative medicine range widely, from the tens of billions to hundreds of billions of dollars. The majority of current revenues derive from tools and research products; few therapeutics have been approved for use, with limited commercial success.

The developing regenerative medicine industry has been driven by academic scientists and clinical entrepreneurs rather than large established life science companies (McKernan, McNeish and Smith 2010; Trounson et al 2011). Academic entrepreneurs possess innovative technical experience, but usually lack knowledge in venturing, scale-up, manufacturing, regulatory environments and health care reimbursement systems. These capabilities are crucial to translate concepts from the bench to the market. Regenerative medicine ventures are, therefore, considered very risky and prone to failure.

Based on five years of research, this chapter examines regenerative medicine commercialization at the university-industry (U-I) boundary from an entrepreneurial perspective. In Section 2, we discuss the complexities faced by university technology transfer offices (TTOs) in translating regenerative medicine. Using the technology transfer process as a backdrop, we explore how individual, structural, cultural, and market-based factors impact regenerative medicine venturing. In Section 3, we discuss how the academic entrepreneur and regenerative medicine venture operate within a wider entrepreneurial ecosystem. In Section 4, we explore business models in regenerative medicine venturing. We note the complex resource requirements, disparate motivations, and market-facing validation challenges of commercializing regenerative medicine innovations. In Section 5, we discuss the implications for academic scientists, TTOs, industry and policymakers.

\subsection{Regenerative medicine technology transfer}

Regenerative medicine venturing immerses scientists and TTOs in complex legal, ethical, 
and commercial environments. The unique aspects of regenerative medicine technology creates conflicts within and among these parties at the U-I boundary (Resnik 2002; Siegel, Veugelers and Wright 2007). In this section, we provide a brief overview of the university technology transfer process and identify the challenges faced by inventing entrepreneurs, TTOs and spin-out ventures associated with commercializing regenerative medicine inventions.

\subsection{A brief introduction to technology transfer}

Many TTOs operate as a department within the host university, but there are other models. The Wisconsin Alumni Research Foundation (WARF), for example, is an independent, not-for-profit foundation supporting research at the University of Wisconsin (WARF 2012). Imperial Innovations, the TTO for Imperial College London, was spun out of the university as a separate legal entity and is now listed on a public stock exchange.

The university technology transfer process model is relatively straightforward. Scientists disclose inventions to the TTO. The office evaluates each innovation for novelty and long-term value. The TTO may seek intellectual property (IP) protection for the invention, usually by filing a patent application. If no patents are filed, ownership rights may devolve to the inventor, a research funder, or even the public, depending on the institution's policies, the provenance of research funding, and other factors (Speser 2006). The TTO may try to monetize IP by licensing, or selling patents or use rights.

Some technology transfer activities have generated significant profits for universities. Examples of significant IP monetization include the patents for Google's search engine, which generated \$330 million in stock value for Stanford, and the royalty stream for the patented pharmaceutical Lyrica, which Northwestern University sold for \$700 million. Major successes are, however, the exception. Relatively few TTO patents are actually licensed, and a minority of licensed patents yield successful products (Feldman et al 2002). More recently, traditional licensing is increasingly being replaced by new technology venturing (NTV) activity and in some instances, direct financial investments by universities into technology ventures through

university venture funds. In the NTV model, the inventing scientists or related parties license the technology to a new venture in exchange for equity rather than upfront payment. Licensing patented innovations to NTVs generates tensions for the academic entrepreneurs and TTOs, 
especially in the field of regenerative medicine technology.

\subsection{Technology transfer offices and regenerative medicine}

TTOs face numerous challenges supporting translation of regenerative medicine innovations. Many TTOs have been charged with four separate and potentially conflicting missions: obtaining IP rights for innovations; maximizing financial returns from IP; enforcing and punishing IP rights infringement; and generating social benefits from university research (Siegel et al 2004). For example, Oxford University's TTO, Oxford University Innovations, states that it “...manages the University's intellectual property portfolio, working with University researchers on identifying, protecting and marketing technologies..." in order to "maximise social and economic benefits in a commercial manner" (ISIS 2012 - italics for emphasis).

Regenerative medicine venturing presents complex institutional and legal issues for TTOs. Regenerative medicine IP has been more contentious and restrictive than many other technologies, especially in the U.S. A limited number of key foundational patents cover fundamental technologies; some TTOs have been relatively aggressive in prosecuting infringement (Bergman and Graff 2007, Nature Biotechnology 2007). The narrow IP regime combined with disparate international patenting policies has dramatically increased the cost of global licensing and enforcement of patent infringement. Further, TTOs must attempt to evaluate regenerative medicine discoveries five, ten, or even twenty years before the market value of an innovation can be credibly tested. Simply, most lack the necessary skill and expertise to forecast market value and access.

Unclear metrics for regenerative medicine commercialization increases the coordination costs of licensee selection and material transfer agreement (MTA) execution. Assigning exclusive rights for cell lines or foundational stem cell technology to a start-up venture risks locking-up the technology for years (Frangioni 2008). Apparently simple technology transfer activities such as MTAs are more complex for stem cells, because agreements must explicitly identify the chain of custody, use-rights, and informed consent (O'Connor 2006). TTOs may bear the legal burden of ensuring that donor informed consent is not violated at any stage from lab work to downstream product use. MTA pricing has been affected by these challenges as well 
as a variety of other factors (McCormick, Owen-Smith and Scott 2009).

Regenerative medicine creates unique tensions for the TTO's social mission. Political and scientific interpretations of the "public good" associated with regenerative medicine have not always been aligned. WiCell, an independent scientific research institute, addresses this directly, noting that its role at founding was in part to serve as "a safe haven for the advancement of stem cell research in the politically charged environment of the time" (WiCell 2012).

Promoting social good through technology transfer is not, in fact, explicit in the dominant legal frameworks governing technology transfer. The Bayh-Dole act only requires that university-based inventions be entrusted to the free enterprise system, protected from "unreasonable use," and commercialized via small businesses where possible (US Code 1980). For TTOs, the balance between potential social good and the obligation to engage with commercial markets may be subject to controversy, even when TTO and University policies are relatively well codified. This is unfortunate, because studies suggest that TTO participation in research commercialization also improves long-term scientific outcomes (Siegel et al 2004).

\subsection{Regenerative medicine entrepreneurs, ventures, and ecosystems}

Innovations do not commercialize themselves. Most TTOs would prefer to license patented technologies to established businesses in exchange for direct financial compensation. In some cases, however, there may be no obvious licensees, often because the technology will require significant additional investment prior to market entry. Relatively few business people actively seek unlicensed university technologies for commercialization. When licensing to an established organization is not evident, the innovators and related members of the academic community are the most likely agents for early-stage commercialization activities (George and Bock 2008).

\subsection{Academic entrepreneurs in regenerative medicine}

Successful academics often demonstrate entrepreneurial characteristics: tolerance for ambiguity, inventiveness and creativity, perseverance, and social networking (Barringer and Ireland 2011). Yet some academic scientists are discouraged by the myth that academics 
participating in commercial activity produce less high-quality research. In fact, participation in the patenting process is generally associated with higher publication productivity (Calderini, Franzoni and Vezzulli 2007). Further, academic scientists who participate in commercialization demonstrate an increase in high-quality research output, especially in the life sciences, where collaboration addresses resource scale requirements (Van Looy, Callaert and Debackere 2006).

At the same time, scientist-entrepreneurs experience a variety of personal and professional conflicts when they engage in commercial activities. These "inventing entrepreneurs" struggle to re-orient from a scientific or technological focus to a market-driven identity (George and Bock 2008). Academic scientists may perceive commercially-oriented activity as secondary or tertiary to their research and career. These inventing entrepreneurs may receive positive or negative feedback from their institutions (Etkowitz 1998). At some research institutions, a stigma may be attached to pursuing commercial outcomes rather than pure knowledge goals. Academic and entrepreneurial roles require significant time commitments; relatively few scientists can invest in both effectively, much less incorporate family and other life activities (Jain, George and Maltarich 2009).

Inventing entrepreneurs may struggle to objectively assess their own affinity for a given technological innovation, the relative importance of that innovation, and the risks associated with commercializing different technology types. For example, life scientists may perceive work on blockbuster therapeutic applications to be more fulfilling - and perhaps rewarding - than inventing research tools or diagnostics:

You have to sell an awful lot of kits to equal one Prozac. It is much more interesting to develop a therapeutic, [even though] there are many more challenges. (Ron Raines, University of Wisconsin-Madison)

Perceptions that career and financial incentives are greater for work in therapeutics are strengthened by funders, which tend to provide more resources for clinical applications than for developing tools, techniques or methodologies.

In regenerative medicine, entrepreneurial scientists must also assess how venturing activity aligns with university and government policies on cell line access. Marketing, distributing, and supporting regenerative medicine-based products requires more administrative and legal oversight than most other university technologies, which may discourage 
entrepreneurial interest. Further, commercializing regenerative medicine technology brings inventing entrepreneurs into complex ethical and legal discussions. Rarely, if ever, has so much media attention been focused on the potential health benefits - and ethical controversies - of a novel technology. Most academic researchers are inexperienced in dealing with the media and various public groups. As entrepreneurs, their work may become even more visible than they would have in their academic labs.

Enthusiasm for technology transfer and de novo venturing has mediated the stigma of participating in commercial activity at some research institutions (Bock 2012). This has been aided by changes in social context, institutional norms and measures of research funding impact (Wolfinger, Mason and Goulden 2009). Regardless, many scientists question whether marketbased financial incentives are the appropriate motivation for regenerative medicine technology transfer.

Just as regenerative medicine innovations have multiple possible technology transfer paths, regenerative medicine scientists experience idiosyncratic entrepreneurial journeys. Some remain dedicated academic scientists, while some transition temporarily or permanently into the commercial realm (George and Bock 2008). The experience of Professor Jamie Thomson at the University of Wisconsin, Madison highlights the rapidly changing nature of role-identity alignment for regenerative medicine scientists:

I went into science having no clue that you could actually make money doing it. When I was in high school, that was when recombinant DNA came out and nobody started biotech companies. Ultimately you go into academics because you love a certain area.... It is very good to keep track of the fact that what you do does have commercial interest, and it is important when you're about to publish that you actually think it through and say, "Does this have commercial value?" (James Thomson, quoted in George and Bock 2008: 269)

The regenerative medicine scientist engaged in entrepreneurial activity must commit to extensive knowledge acquisition, and significant investments of time and energy. Partnering with experienced industry professionals and companies with the expertise in resource management, marketing, regulatory affairs, public relations and other areas the scientist may lack will go a long way toward making venturing more successful. 
Our research into this field has revealed that regenerative medicine venturing is driven by how academic entrepreneurs make sense of the uncertainties associated with commercialization activities. When information gathering and analysis cannot resolve uncertainty, academic entrepreneurs must make decisions under significant uncertainty. Entrepreneurs address this uncertainty with a problem-based coping mechanism or ignore it via an emotion-based coping mechanism (Johnson and Bock 2017). The choice of coping response has important implications for the regenerative medicine ecosystem. Our investigations into regenerative medicine venturing across the UK, U.S. and Russia reveal that entrepreneurial coping mechanisms are directly linked to the entrepreneurial culture within the university (Bock and Johnson 2016a).

While individual cognitive factors are important, successful commercialization of a regenerative medicine invention still requires a market-facing commercial entity: the regenerative medicine venture.

\subsection{The regenerative medicine venture}

New technology venturing is a complex and resource intensive process. Regenerative medicine spin-outs face special hurdles associated with knowledge collaboration, operations, funding, and exit uncertainty.

Knowledge sharing and partnership, including U-I collaborations, are valuable in technologically complex industries (Powell, Koput and Smith-Doerr 1996; Zucker and Darby 1996). Regenerative medicine therapeutics could resolve the shrinking pipeline of novel pharmaceutical compounds without cannibalizing existing products and generate returns beyond the patent life horizon because treatments could be based on cell lines inaccessible to competitors (Denoon and Vollebregt 2010). While partnering activity has increased recently, the major pharmaceutical companies have not made significant investments in foundational and early stage regenerative medicine technologies due to concerns about efficacy, regulations, liability, and unproven cost/benefit against extant treatments (McKernan et al 2010). Additionally, market access and reimbursement uncertainties further complicate matters. Pharmaceutical companies are taking fewer risks in collaborative activities and tying payments to results rather than funding exploratory research (Rockoff and Tam 2012). 
The industry has struggled under burdensome regulations, unreasonable expectations, and increasingly conservative venture capitalists, while trying to push forward an untested form of therapy that everyone knows will be expensive to implement (Ledford 2008).

Without partnering, new regenerative medicine ventures are less likely to develop deep capabilities needed to explore related technological and market opportunities (George, Kotha and Zheng 2008). In our research, we found that entrepreneurial propensities for knowledge exchanges and partnering are culturally driven. When the host university emphasizes a high degree of entrepreneurial culture, we recorded greater levels of partnering and development of knowledge capabilities. When entrepreneurial culture at the research institution is inhibited, academic entrepreneurs are less likely to seek out partnerships and knowledge-based collaborations. The latter situation is especially problematic for regenerative medicine ventures.

Regenerative medicine ventures must also overcome numerous operations challenges. To date, only a few companies have demonstrated successful scale-up of cell production under good manufacturing practice (GMP). The legal and regulatory environments for research and commercial use of stem cells in the U.S. remain uncertain (Fink 2009). Although Japan has made significant efforts to streamline the regulatory process for regenerative medicines, the global regulatory context is complex and inconsistent. As one example, the CEO of one UK regenerative medicine venture we interviewed noted that initiating clinical trials required consultation and document filings with five different government departments.

Regenerative medicine therapeutics ventures face especially significant funding hurdles. Therapeutic development and clinical testing generally exceed venture capital fund time horizons and investment limits. The time and costs for development and testing of regenerative medicine therapeutics are beyond the reach of all but the largest venture capital and pharmaceutical firms.

Tools and diagnostics companies may not share this problem, but may be significantly hampered by uncertain product specification. Early stage regenerative medicine tool companies may not be certain about downstream use, because manufacturing, distribution and use characteristics cannot be confirmed until clinicians actually test products on site.

Regenerative medicine spin-outs led by scientists may face skepticism from commercial funders, who may perceive that scientists are not prepared for venture management. Scientists often prefer to maintain multiple technological options, while venture capitalists prefer to invest 
in ventures that focus resources on one high-potential innovation. Further, the skills associated with managing large projects and teams at the university may not fully transfer to the commercial context (George and Bock 2008). While the efficacy of broad-based entrepreneurship training remains uncertain, targeting specific skill deficiencies to a self-selected and engaged audience of potential inventing entrepreneurs could prove valuable (Siegel and Phan 2005). In regenerative medicine, experiential training that directly address coping with failure and knowledge capability development is most likely to be the most effective form of training over any other skill-based emphasis.

Meanwhile, the broader context for funding biotechnology ventures has been challenging. High-profile government funding schemes in some countries can complement, not replace private capital sources. Venture capital funding for biotechnology has fluctuated dramatically with broader economic and market conditions, as well as industry-specific events, such as the exit of Geron from the regenerative medicine field. Venture capitalists remain skeptical of regenerative medicine technologies and product distribution because of the inherent uncertainties and unknown unknowns (Giebel 2005).

Many of the challenges associated with regenerative medicine venture financing and development can be attributed to the exit problem. Venture capitalists prefer investments with a clear path to exit, usually through the sale of the organization, monetization of its assets, or more rarely, an initial public offering. Successful exit events tend to be large transactions requiring high levels of capital liquidity. Funding for exit activity in the life science sector generally has been limited since 2001. Regenerative medicine company funding is further hampered by the limited number of potential acquirers and concerns about long term liabilities associated with regenerative medicine treatments (Cyranoski 2012; Taylor 2012).

Starting, sustaining, and growing a regenerative medicine venture does not happen in a vacuum. Although most critical success factors for regenerative medicine venturing can be linked to the team and technology, the venture must operate within a larger industrial organizational context. Within the management literature, the focus of analysis has shifted from a cluster of competitors to an ecosystem of related and co-dependent organizations. Of particular interest are entrepreneurial ecosystems that nurture high growth and technology ventures. 


\subsection{Regenerative medicine entrepreneurial ecosystems}

Entrepreneurial ecosystems have become important considerations in university and government policy making (Mason and Brown 2014). The development of regenerative medicine entrepreneurial ecosystems at the U-I boundary is a complex, context-specific phenomenon. Prior research into entrepreneurial ecosystem development has predominantly emphasized the importance of environmental conditions and policy. In the context of venturing uncertainty, however, these factors alone are insufficient to explain ecosystem outcomes at the U-I boundary (Bock and Johnson 2016a). Institutional policies, practices and resources are fundamental requirements to support entrepreneurial ecosystems. However, uncertainty during regenerative medicine commercialization highlights the agency of the academic entrepreneur.

In particular, high levels of unresolvable uncertainty in regenerative medicine requires entrepreneurs to makes sense of venturing uncertainties through the implementation of preferential coping mechanisms and collaboration strategies. Our prior research revealed that when information gathering and analysis cannot resolve uncertainty, the decision-making abilities of academic entrepreneurs is challenged. Entrepreneurs have the choice to either address this uncertainty directly through a problem-based coping response, or chose to ignore it, acting through an emotion-based coping mechanism (Johnson and Bock 2017).

Our investigations into regenerative medicine venturing across the UK, U.S. and Russia reveals that entrepreneurial coping mechanisms to uncertainty are largely driven by the entrepreneurial culture within the university. When universities emphasized a strong culture for entrepreneurship, the result was a focus on problem-based coping strategies. In contrast, a low culture for entrepreneurship at the university was associated with emotion-based coping strategies (Bock and Johnson 2016a).

Both coping and culture are associated with collaboration efforts at the U-I boundary. More specifically, we witnessed greater collaboration effort at the U-I boundary when the ecosystem emphasized problem-based coping along with higher levels of entrepreneurial culture. Reduced collaboration efforts were indicative of an ecosystem that emphasized emotion-based coping and reduced entrepreneurial culture. Since we have already discussed the importance of collaboration and partnering from a knowledge and capabilities perspective, the latter situation is problematic for regenerative medicine ventures. 
Thus, the choice of coping response has important implications for the types of spinout ventures at the U-I boundary and the regenerative medicine ecosystem. Our prior research revealed a typology of regenerative medicine ecosystem types. Shown in Figure 1, these ecosystem types derive from the degree of partnership development at the U-I boundary and the dominant coping response to uncertainty (Bock and Johnson 2015).

\section{Figure 1 About Here}

Healthy ecosystems are characterized by problem-based coping and collaborative knowledge development. We believe these ecosystems best adapt and respond to the uncertainties inherent to regenerative medicine technology transfer and venturing (George et al 2008).

Insular domains are ecosystems where firms problem-solve but collaborate poorly. This generates a parochial network of firms that rely predominantly on internal knowledge and resources for venturing. In these ecosystems, entrepreneurs and ventures utilize their problemsolving capabilities to primarily focus on challenges within the organization and its immediate context, rather than exploring broader market opportunities. When the technology, team, and application are well-designed (and, perhaps, lucky) these ecosystems may appear healthy, despite lacking the ability to collaborate for knowledge creation and new opportunities. Since regenerative medicine venturing operate within a high-uncertainty environment, we believe that ventures that rely solely on their extant capabilities and knowledge are significantly at risk for missing key trends and market changes.

Networks of ignorance form when venturing activity utilizes collaboration in the context of an emotion-based coping strategy. Emotion-based coping ignores the impact of uncertainty and the need for adaptation. This type of collective behaviour can be especially dangerous, because it presents the appearance of market-facing activity, via networking, while actually encouraging entrepreneurs and ventures to connect only with like-minded participants. Homophily effects can lead these firms to collaborate with similar firms who equally have similar misconceptions of specific technologies and/or commercialization models.

Disengaged cohorts result from poor knowledge collaboration and an emotion-based coping strategy. In these groups and ecosystems, entrepreneurs and ventures attempt to execute 
one commercialization model without feedback or the ability to adapt. We believe that such ecosystems are almost certain to fail.

\subsection{Regenerative medicine business models}

A key inhibitor to regenerative medicine commercialization is the lack of proven business models. In this section, we describe the business model challenge for regenerative medicine ventures, summarize regenerative medicine business model research, and suggest an approach to characterize general regenerative medicine business models. We also discuss business model innovation in the regenerative medicine industry.

\subsection{Business model design in the life sciences}

A business model is the design of the organization to exploit a commercial opportunity (George and Bock 2011). In other words, a business model provides a map of key organizational elements that shows how the entity creates and captures value to succeed as a viable commercial venture.

Various studies have assessed dominant business models in the life sciences industry, focusing on one of three organizational characteristics. Some distinguish between innovationdriven versus market-driven activities (Willemstein, van der Valk and Meeus 2007). Others distinguish product, service, and platform businesses (Patzelt, Knyphausen-Aufsess and Nikol 2008). Finally, some emphasize vertical integration from research and materials provision through end-use (Bigliardi, Nosella and Verbano 2005; Nosella, Petroni and Verbano 2005).

Broadly speaking, new life science ventures utilize a technology innovation or platform to target a specific application or market space. Inherent resource limitations require most technology ventures to focus on one product or indication at a time.

The "blockbuster" pharmaceutical business model is predicated on a treatment modality in which patients receive long-term treatments over many years. The advent of regenerative medicine cures for long-term, chronic ailments presents challenges for pricing and reimbursement. A value-based pricing policy for a cure, rather than lifetime treatment, may not present sufficient financial returns to justify the required investment in R\&D and clinical trials.

In the near-term, services and tools ventures have the clearest path to viable business 
models. No clinical trials are required to sell such products for R\&D use by other organizations. These firms therefore require smaller investments and generate, on average, commensurately smaller returns. Similarly, diagnostics and related pre-treatment mechanisms have a significantly reduced regulatory requirement compared to treatments.

\subsection{Exploring business models in regenerative medicine}

Regenerative medicine ventures will likely use a wide spectrum of models to serve a variety of business and patient markets. Some general business models in the life sciences industry will be relevant for regenerative medicine ventures. Some will be highly localized, adapted to rapid physical delivery of cultured cells from production site to clinical application. It is conceivable that this type of business model could be franchised, with disparate, small-scale production facilities supporting local clinical treatments. Others will be global and fully integrated, competing with or subsumed by the pharmaceutical companies. It is quite possible that the treatment potential for certain diseases will become matters of government interest. This could generate quasi-governmental organizations, or special purpose public-private partnerships, that oversee or even implement production and distribution of certain tools or treatments.

Some regenerative medicine ventures, however, will require entirely new business models, especially as the industry evolves (Heirmann and Clarysse 2004). Entrepreneurs and policymakers must remember that the major pharmaceutical companies have significant advantages in slack resources, scale-up capacity, market knowledge, and distribution relationships. They will be favored by innovations that utilize explicit and transferable capabilities, assets, and IP. Tacit and time-based capabilities are therefore critical to the success of new entrants. If innovative business models utilize tacit capabilities and technologies that are costly to transfer or acquire, then new, innovative regenerative medicine ventures could achieve significant success.

\subsubsection{Towards a typology of business models in regenerative medicine}

To develop a more useful typology of regenerative medicine business models, we utilize a general framework from organization studies. Although many different frameworks have been 
proposed for understanding business models, the simplest and most clear relies on three general components or structures: resources, transaction, and value (George and Bock 2011). The resource structure of the firm is the configuration of assets, knowledge, and capabilities leveraged to meet market needs. These are, in effect, all the "things" that give an organization an advantage over other organizations. Transactive structure describes the type, content, and governance of interactions with suppliers, partners, and customers (Amit and Zott 2001). These are all the connections and exchanges that the organization engages in, with both individuals and entities, in order to convert resources into outcomes that are valuable. The value dimension represents the type and form of value actually created for customers and other stakeholders (Afuah and Tucci 2000). ${ }^{1}$

A generalized business model typology for regenerative medicine companies must incorporate whether the firm targets therapeutics or enables therapeutic development by other firms, the nature of the cell technology, manufacturing requirements, and distribution characteristics. Limitations on cell survival as well as idiosyncratic and specialized delivery requirements may be key determinants in the structure of successful regenerative medicine businesses.

Based on the prior literature of life science venturing, regenerative medicine business models can be described with eight determining categories. The resource structure includes cell delivery model, level of vertical integration, and resource differentiator. The transactive structure includes customer type, manufacturing specificity, and distribution scale. The value structure includes value form and type. This classification for regenerative medicine business model categories and organizational elements is shown in Table 1.

Table 1 about here

Corporate strategy suggests that a viable business model uses one and only one element

${ }^{1}$ It is, unfortunately, impossible to quickly recapitulate the organizational literature on business models and how they function. Interested readers are directed to the following for an introduction to business models in theory and practice: Bock and George 2018; George and Bock 2011; Nosella et al 2005; Teece 2010; Zott, Amit and Massa 2011. 
from each category (Hill and Rothaermal 2003). Addressing more than one element within a category makes the organization vulnerable to focused competitors via inefficient operations or poor fit with market segment characteristics (Markides and Charitou 2004; Porter 1998). It is important to note, of course, that new and established ventures often operate parallel business models or test multiple business models during exploratory periods. Business model theory suggests that such experimentation is valuable (George and Bock 2012); corporate strategy theory suggests that longer-term competitive success depends on moving from experimentation to implementation.

The eight dimensions and twenty elements in the typology suggest hundreds of business models are possible, but only a limited number will prove to be viable. To date, relatively few have been tested. The only proven models have been demonstrated primarily at firms providing niche products and services supporting therapeutic development. Equally important, not all possible business models are viable at scale.

To explore the business model space in the context of regenerative medicine, we consider three case examples. Cellular Dynamics International, acquired by FujiFilm, commercialized foundational stem cell and induced pluripotent stem cell (iPSC) technology developed by James Thomson. Cellular Logistics, a spin-out of the Wisconsin Institute for Medical Research, is commercializing an extracellular matrix as a cardiac therapeutic and cell delivery platform. Censo Biotechnologies, formerly Roslin Cells, is a hybrid entity originally spun out of the University of Edinburgh. These mini-cases present only the minimum information to explore possible business models. The examples provide only a thin slice of the variety of regenerative medicine ventures already in existence and business models yet to be tested.

\subsubsection{Testing and selecting basic business models in regenerative medicine - Cellular Logistics}

Cellular Logistics² (CLI) was formed in 2016 to commercialize an extracellular matrix developed at the Wisconsin Institute for Medical Research at The University of Wisconsin-

\footnotetext{
${ }^{2}$ Full disclosure: Adam J. Bock, Eric Schmuck, Amish Raval, and Peiman Hematti are the co-founders of Cellular Logistics. Data collection and analysis for this mini-case were implemented by David Johnson who has no relationship to the company.
} 
Madison. Dr. Eric Schmuck discovered the biomaterial during doctoral research on cardiac fibroblasts. The innovation was patented by the WARF in 2014. Working with Dr. Amish Raval, an interventional cardiologist, Schmuck determined that the matrix demonstrated proregenerative characteristics in a myocardial infarction mouse model. Since that time, the technology has also been demonstrated to significantly improve cell retention when delivered as a combination product.

As of the writing of this chapter, CLI is still exploring possible business models. The use of the company's acellular ECM as a cardiac therapeutic represents a relatively standard life science therapeutic business model. As previously noted, however, the economics of a business model based on curative rather than long-term treatment have not been fully demonstrated.

The cell delivery embodiment presents at least two alternative business model options. For example, the company could in-license cell or regenerative medicine products and attempt to commercialize combination therapeutic products. Alternately it could out-license or sell the cell delivery product for other regenerative medicine therapeutics companies.

Three possible business models for CLI are shown in Table 2. Each requires different resources and presents a distinct risk-reward profile to founders, partners, and investors. Many, if not most, de novo ventures in the regenerative medicine field will face similar business model challenges and choices.

Table 2 about here

4.2.3. Hybrid business models in regenerative medicine venturing - Censo Biotechnologies

Some universities have participated in novel, hybrid institutional activities to support regenerative medicine venturing (Aboody et al 2011). These include one-off entities such as incubators and government funding schemes. It is unclear, however, whether such systems promote success by supporting the organization during the critical, fragile launch period or facilitate failure by shielding the organizations from the market and industry forces that it must eventually address and overcome (Rothaermel and Thursby 2005). Even direct investments by 
universities into regenerative medicine centers of excellence may not be enough to promote commercialization activities, which may be ultimately driven at the level of the central research institution. Censo Biotechnologies Ltd. is a regenerative medicine technology company providing human cells and contract research services for drug discovery, toxicity testing and cell banking. It began operations in 2006 as Roslin Cells, which was spun out of The University of Edinburgh's Roslin Institute. Roslin Cells was a not-for-profit organization, whose activities spanned the development of cell therapies, and GMP manufacturing services for cell therapy products and mammalian cell banks for clinical use. Roslin Cells also provided a range of pluripotent stem cells for clinical use and research. In 2008, Roslin Cellab was created as a sister-company to Roslin Cells since certain commercialization activities were felt to be incompatible with the not-for-profit status of Roslin Cells. This for-profit organization was responsible for assisting organizations in developing products and services for the regenerative medicine space via access to both stem cells and regenerative medicine know-how. Both Roslin Cell and Roslin Cellab had to undergo some critical adjustments to their respective business models. The ethical controversies surrounding the use of embryonic stem (ES) cells saw both organizations alter their commercialization activities to one that centered around the use of iPSCs rather than ES cells.

In 2016, Roslin Cells announced the creation of two subsidiaries. The first subsidiary, Roslin Cell Therapies, would accelerate the process development and manufacture of cell-based therapies and Advanced Therapy Medicinal Products (ATMPs). The second subsidiary, Roslin Cell Sciences, would focus on the development of iPSCs for commercial and academic drug use. In May 2016, Roslin Cellab and Roslin Cells Sciences announced a merger, with the parent company being renamed Censo Biotechnologies. Roslin Cell Sciences would continue to trade as a wholly owned subsidiary.

This case clearly highlights the complexities of operating within the regenerative medicine commercialization space. Since founding in 2006 as a spin-out from The University of Edinburgh, Censo's business model changed from a not-for-profit organization to a hybridized for-profit and not-for profit organization. Censo also switched from human ES cells to iPSCs due to ethics-related concerns. Finally, the new organization spans both services and therapeutics. 
Table 3 about here

\subsubsection{Business model innovation in regenerative medicine venturing - Cellular Dynamics} International

Although business models have received extensive attention in organizational literature, business model innovation is relatively unstudied. Business model innovation is a "known unknown" in regenerative medicine venturing. Successful business model innovation may not be predicted by prior innovation success (Bock et al 2012). In other words, today's failing spin-out company may be tomorrow's regenerative medicine business model innovator. Even successful business model innovators, however, may not capture the value of their pioneering efforts. The winners of radical innovation stages are determined by whether inventions rely on extant capabilities or require entirely new technology and process capabilities (Tripsas 1997). Innovative business models can dramatically disrupt industries, bringing new competitors to the field, function alongside incumbent communities, or even reinforce the advantages of the incumbents.

It is, therefore, useful to consider examples of business model innovation to explore how such processes unfold. Cellular Dynamics (CD) provides an example of configurational business model innovation in the regenerative medicine space.

CD was originally formed as two entities spun out of University of Wisconsin-Madison based on the research of James Thomson. As a stand-alone firm, CD was a world leader in supplying mass produced stem cells as drug discovery research and development tools. The company also maintained long-term research to develop cell-based treatments, with special interest in blood therapeutics. This configuration of separate entities aligned with traditional strategic frameworks that separate business models based on risk-reward profiles (Markides and Charitou 2004). After licensing iPSC technology from WARF, the distinct entities were merged in 2008 to pursue both tools and therapeutics.

In a prior study, we used neural network analysis to simulate possible business models for the entity (George and Bock 2012). Possible options included a "null" solution in which all 
business model elements were inactive as well as a focused therapeutics business and a variant of the two-entity solution. While these outcomes were coherent and plausible, they emerged in relatively few of the simulation runs.

Table 4 shows CD's business model change, including two of the plausible business model innovations identified by the simulation.

The change process selected by management (and by the neural network) created a coherent platform-based business model incorporating partly inconsistent organizational elements. The internal inconsistencies created resource allocation challenges across the tools and therapeutics operations of the combined organization. Despite these "flaws," the new configuration was internally coherent, which facilitated fundraising and helped management prioritize scale-up manufacturing, partnering, and marketing activities. CD was named the most innovative company in the world in 2011 by The Wall Street Journal. In 2015, CD was acquired by FujiFilm for USD \$315 Million.

Table 4 about here

As previously noted, the typology hints at hundreds of possible business models that have yet to be formalized or tested. Possible business model innovation examples include not-forprofit treatment systems targeted at poor populations, disease-specific long-term treatment centers that align with the U.S reimbursement system, and public-private partnerships that link the cell culturing infrastructure of large research institutions with specialized, localized delivery. Cooperation among disparate economic participants, including government, philanthropy, and national health agencies, suggests that innovative solutions aligned with both physical delivery and payment systems could achieve rapid adoption. Developing business model innovation types include Lonza's strategic manufacturing relationship with NIH CRM and Life Technology's development of a horizontally integrated platform of research and manufacturing tools. Again, it is too early to be sure whether these represent commercially viable business model innovations. 


\subsection{Facing reality in regenerative medicine entrepreneurship}

To date, the promise of regenerative medicine science has not yielded significant advances in human health care and outcomes. While the general consensus of scientists and businesspeople remains positive, the near- and mid-term reality requires pragmatism.

\subsection{The flawed narrative of regenerative medicine entrepreneurship}

In a developing industry like regenerative medicine, where technological innovation confers significant value, strategic analysis can be misleading (Goerge and Bock 2012). In this context, entrepreneurs succeed by accomplishing what other firms find impossible:

Entrepreneurship is a process by which individuals-either on their own or inside organizations-pursue opportunities without regard to the resources they currently control (Stevenson and Jarillo 1990).

Entrepreneurship inspires heroic narratives precisely because it strives against the odds. Similarly, regenerative medicine science aims to radically improve health care outcomes. The combination of entrepreneurial action and regenerative medicine potential has proven irresistible to scientists, institutions, entrepreneurs, financiers, and governments, as a narrative of hope and promise. Narratives of emotion and cognition are important sensemaking devices (Byrne and Shepherd 2013). In regenerative medicine, the narrative structures that address venturing uncertainty encourage entrepreneurs to perceive their efforts within a heroic context, precisely because of unrealistic expectations for commercial and societal impact.

Despite sometimes glowing depictions in the media, however, entrepreneurship is not generally a mythical, heroic endeavor. Most risk-capital funded technology ventures fail within five years of founding. The significant majority of venture-capital funded life science ventures will not bring a product to market. 


\subsection{The role of failure in regenerative medicine venturing}

Failure is an unavoidable aspect of entrepreneurial activity. Industry-level advances almost always induce a high failure rate during innovation phases. In fact, high levels of experimentation and concomitant failure are directly linked to higher levels of community-level learning and evolution (Bernardo and Welch 2001). Even well-funded, proven competitors may struggle.

"Every [regenerative medicine] venture cannot possibly be successful" (Perkel 2011).

The challenges of regenerative medicine commercialization were exemplified by failure at Geron, a pioneer in the field (Scott and Huggett 2012). Regenerative medicine ventures are exposed to significant risks, which can be quantified and managed, and uncertainties, for which firms can only prepare and hope to adapt (Knight 2006). The reality of most regenerative medicine venturing activity is a constant struggle with both real and perceived failure. As one venture founder and $\mathrm{CEO}$ explained to us:

"I went to a meeting in India with the company, I did some seminars and things there; I've done all sorts of things... but things are not progressing very well this year, and really if things don't really start picking up I really need to think about perhaps doing something else."

The problem is that regenerative medicine venturing carries high costs in research infrastructure, patent prosecution, and venture support. This has led some universities, TTOs, and even funders to reject venture failure as an option. In these cases, institutions and individuals continue to support regenerative medicine ventures long after the technological innovation or business model has proven infeasible.

We have heard institutional stakeholders defend this approach with cluster economics theory, based on the idea that a critical mass of regenerative medicine commercial activity will become self-sustaining (Porter 1990). This is an understandably attractive argument, in which the key ingredients for a thriving commercial regenerative medicine ecosystem are sufficient finance and staying power. But, keeping "dead" ventures alive is problematic for regenerative medicine 
ecosystems. Valuable resources become locked into ventures that could otherwise be redeployed within the ecosystem to better purpose (Baumol 1990; Stam 2015). This includes capital, people, and technology.

Worse, facilitating regenerative medicine venturing activity will not automatically lead to large, successful businesses tied to the local community (Miner et al 2001). The only guaranteed outcome of facilitating more ventures is more failed ventures. Overemphasizing the importance of local ventures may also be misguided. Since robust entrepreneurial ecosystems have porous boundaries, protecting boundaries too rigorously will only hinder the development of a healthy and resilient ecosystem. The development of viable industry clusters or ecosystems requires a complex set of factors not easily reproduced via extra-market programs and incentives (Menzel and Fornahl 2010).

Scientists choosing to participate in the commercialization of their regenerative medicine research should carefully assess their own motivations. Researchers primarily interested in financial gain, responding to institutional or peer pressure, or high levels of technology affinity, are likely to experience disappointing results. On the other hand, scientists interested in the commercialization process, or engaged in addressing specific medical problems, are likely to build and extend their own capabilities. Researchers may further their academic career regardless of the ultimate disposition of the specific technology or venture.

\subsection{The TTO funding and returns problem}

It is unlikely that new models for funding will significantly impact licensing or spin-out activities. Because pharmaceutical partnering and venture capital thrives on economies of scale and informal networks, a limited number of ventures from a select set of university research programs will likely continue to receive the lion's share of early stage investment. In addition, being first to market is a dramatically different proposition than being first to the FDA with a novel therapeutic treatment. This suggests that most TTOs supporting first generation regenerative medicine technologies (with the possible exception of institutions with key foundational patents) will achieve low long-term financial rewards. The returns on secondgeneration regenerative medicine medicines may be significantly higher.

Ultimately, the challenge facing TTOs commercializing regenerative medicine 
innovations is the selection of success metrics. Even the most efficient, effective TTOs will struggle to support extensive development activities spanning discovery to monetization. Setting up non-profit distribution entities such as Roslin Cells and WiCell may provide a partial solution to the commercialization challenge, but is unlikely to generate the long-term yields associated with upfront, high-risk investments. The perceived social value of regenerative medicine has challenged the presumption that TTO returns should primarily accrue to the TTO and the institution. In the long run, TTOs may find that balancing regenerative medicine patenting, licensing, and venturing outcomes requires more explicit prioritization, especially as pricing and distribution models for disease treatment evolves.

\subsection{Focusing on the ecosystem rather than the innovation}

Our findings suggest that universities, TTOs, and policymakers should focus attention on the ecosystem when evaluating commercialization outcomes (Bock and Johnson 2016b). This is especially important because the direct economic impact of technology transfer, especially NTV activity, is often overstated (e.g. Breznitz and Feldman 2012; Feldman et al 2002; Miner et al 2001). Further, efforts by universities and policymakers to copy practices from mature successful ecosystems tend to be unsuccessful. While some best practices may be imitable (Graham 2014), transplanting entire programs or structures ignores critical, localized idiosyncrasies in culture, entrepreneurial norms, and institutional context. In other words, TTOs and policymakers need to understand the nature of the local and regional ecosystem to effectively develop metrics of success that incentivize and reinforce problem-based coping and knowledge collaboration activities. Supporting one innovation at a time appears to be the shortest path to commercial success, but ultimately it is the health of the ecosystem that will determine long-term economic outcomes.

\subsection{Conclusions}

Regenerative medicine venturing at the U-I boundary is complex, difficult, and uncertain. Conflicting motivations across individuals and organizations create tensions for scientists, entrepreneurs, and institutions. In the short term, firms that focus on tools, services and 
diagnostics present more viable business models than ventures based on novel regenerative medicine therapeutics. Resolution of regulatory, delivery, pricing, reimbursement, and exit uncertainty will determine whether innovative business models favor upstarts or incumbents. In the meantime, inventing entrepreneurs, TTOs, and policymakers should approach regenerative medicine venturing with realistic and appropriate metrics for success, and with any eye towards the development of healthy entrepreneurial ecosystems. 


\section{References}

Aboody, K., Capela, A., Niazi, N., Stern, J.H. \& Temple, S. (2011). Translating stem cell studies to the clinic for CNS repair: Current state of the art and the need for a Rosetta Stone. Neuron, 70(4): 597-613.

Afuah, A. \& Tucci, C.L. (2000). Internet business models and strategies: Text and cases. McGraw-Hill Higher Education.

Amit, R. \& Zott, C. (2001). Value creation in e-business. Strategic Management Journal, 22(6/7): 493-520.

Barringer, B.R. \& Ireland, D. (2011). Entrepreneurship: Successfully launching new ventures. Prentice-Hall Pearson: Saddleback, New Jersey.

Baumol, W.J. (1990). Entrepreneurship: productive, unproductive and destructive. Journal of Political Economy, 98: 893-921.

Bergman, K. \& Graff G.D. (2007). The global stem cell patent landscape: Implications for efficient technology transfer and commercial development. Nature Biotechnology, 25: 419424.

Bernardo, A. \& Welch, I. (2001). On the evolution of overconfidence and entrepreneurs. Journal of Economics and Management Strategy, 10(3): 301-330.

Bigliardi, B., Nosella, A. \& Verbano, C. (2005). Business models in Italian biotechnology industry: A quantitative analysis. Technovation, 25(11): 1299-1306.

Bock, A.J. \& George, G. (2018). The Business Model Book: Design, Build and Adapt Business Ideas that Thrive. Pearson, United Kingdom.

Bock, A.J. \& Johnson, D. (2015). Entrepreneurial ecosystems: Fixing the Triple Helix. The European Business Review, November-December, 73-76.

Bock, A.J. \& Johnson, D. (2016a). A comparative study of ecosystem development in regenerative medicine. In Phan, P. (Ed.), Academic Entrepreneurship: Translating Discoveries to the Marketplace. Edward Elgar: Cheltenham, United Kingdom, 218-250.

Bock, A.J. \& Johnson, D. (2016b). The uniqueness of stem cell ecosystems: Lessons in matching local culture. Coller Venture Review, 4: 42-53. 
Bock, A.J. (2012). “Technology Transfer” in (ed. Marvel) Encyclopedia of New Venture Management. SAGE Publications: Thousand Oaks, CA.

Bock, A.J., Opsahl, T., George, G. \& Gann, D.M. (2012). The effects of culture and structure on strategic flexibility during business model innovation. Journal of Management Studies, 49(2): 279-305.

Breznitz, S.M. \& Feldman, M.P. (2012). The larger role of the university in economic development: Introduction to the special issue. The Journal of Technology Transfer, 37(2): 135-138.

Byrne, O. \& Shepherd, D.A. (2013). Different strokes for different folks: Entrepreneurial narratives of emotion, cognition and making sense of business failure. Entrepreneurship Theory and Practice, 39(2): 375-405.

Calderini, M., Franzoni, C. \& Vezzulli, A. (2007). If star scientists do not patent: The effect of productivity, basicness and impact on the decision to patent in the academic world. Research Policy, 36(3): 303-319.

Cyranoski, D. (2012). Patients seek stem-cell compensation. Nature.com, July 6, 2012. Accessed online on 17-Sept 2012 at http://blogs.nature.com/news/2012/07/patients-seek-stem-cellcompensation.html.

Denoon, A. \& Vollebregt, E. (2010). Can regenerative medicine save Big Pharma's business model from the patent cliff? Regenerative Medicine, 5(5): 687-690.

Etzkowitz, H. (1998). The norms of entrepreneurial science: Cognitive effects of the new university-industry linkages. Research Policy, 27(8): 823-833.

Feldman, M., Feller, I., Bercovitz, J. \& Burton, R. (2002). Equity and the technology transfer strategies of American research universities. Management Science, 48(1): 105-121.

Fink, D.W. (2009). FDA regulation of stem cell-based products. Science, 324(5935): 1662-1663.

Frangioni, J.V. (2008). The impact of greed on academic medicine and patient care. Nature Biotechnology, 26(5): 503-507.

George, G. \& Bock, A.J. (2008). Inventing Entrepreneurs. Prentice Hall Pearson: Saddleback, New Jersey. 
George, G. \& Bock, A.J. (2011). The business model in practice and its implications for entrepreneurship research. Entrepreneurship Theory and Practice, 35: 83-111.

George, G. \& Bock, A.J. (2012). Models of Opportunity. Cambridge University Press.

George, G., Kotha, R. \& Zheng, Y. (2008) Entry into insular domains. A longitudinal study of knowledge structuration and innovation in biotechnology firms. Journal of Management Studies, 45(8), 1448-1474.

Giebel, L.B. (2005). Stem cells - A hard sell to investors. Nature Biotechnology, 23(7): 798-800.

Graham, R. (2014). Creating university-based entrepreneurial ecosystems: Evidence from emerging world leaders. Massachusetts Institute of Technology Report: Cambridge, MA.

Heirman, A. \& Clarysse, B. (2004). How and why do research-based start-ups differ at founding? A resource-based configurational perspective. The Journal of Technology Transfer, 29, (3-4): 247-268.

Hill, C.W.L. \& Rothaermel, F.T. (2003). The performance of incumbent firms in the face of radical technological innovation. Academy of Management Review, 28(2): 257-274.

ISIS Innovation website, Oxford University. Accessed on 14-September 2012 at http://www.isisinnovation.com/about/index.html

Jain, S., George, G. \& Maltarich, M. (2009). Academics or entrepreneurs? Investigating role identity modification of university scientists involved in commercialization activity. Research Policy, 38(6): 922-935.

Johnson, D. \& Bock, A.J. (2017). Coping with uncertainty: Entrepreneurial sensemaking in regenerative medicine venturing. The Journal of Technology Transfer, 42(1): 33-58.

Knight, F.H. (2006). Risk, Uncertainty and Profit. Houghton Mifflin Co: Boston.

Ledford, H. (2008). In search of a viable business model. Nature Reports Stem Cells, October 30, 2012. Accessed online on 17-September 2012 at http://www.nature.com/stemcells/2008/0810/081030/full/stemcells.2008.138.html

Markides, C. \& Charitou, C.D. (2004). Competing with dual business models: A contingency approach. The Academy of Management Executive (1993-2005): 22-36.

Mason, C. \& Brown, R. (2014). Entrepreneurial ecosystems and growth entrepreneurship. 
Background paper prepared for the workshop organised by the OECD LEED Programme and the Dutch Ministry of Economic Affairs on entrepreneurial ecosystems and growth orientated entrepreneurship, The Hague, Netherlands, $7^{\text {th }}$ November 2013.

McCormick, J.B., Owen-Smith, J. \& Scott, C.T. (2009). Distribution of human embryonic stem cell lines: Who, when, and where. Cell Stem Cell, 4(2): 107-110.

McKernan, R., McNeish, J. \& Smith, D. (2010). Pharma's developing interest in stem cells. Cell Stem Cell, 6(6): 517-520.

Menzel, M.P. \& Fornahl, D. (2010). Cluster life cycles-dimensions and rationales of cluster evolution. Industrial and Corporate Change, 19(1): 205-238.

Miner, A.S., Eesely, D.T., DeVaughn, M. \& Rura, T. (2001). The magic beanstalk vision of university venture formation. The Entrepreneurship Dynamic: Origins of Entrepreneurship and its Role in Industry Creation and Evolution. Stanford University Press, Stanford, CA.

Nature Biotechnology (2007). "Burning Bridges” - Editorial. 2007. Nature Biotechnology, 25:2.

Nosella, A., Petroni, G. \& Verbanoc, C. (2005). Characteristics of the Italian biotechnology industry and new business models: The initial results of an empirical study. Technovation, 25(8): 841-855.

O'Connor, S. (2006). The use of MTAs to control commercialization of stem cell diagnostics and therapeutics. Berkeley Technology Law Journal, 21(3): 1017-1054.

Patzelt, H., Knyphausen-Aufsess, D.Z. \& Nikol, P. (2008). Top management teams, business models, and performance of biotechnology ventures: An upper echelon perspective. British Journal of Management, 19(3): 205-221.

Perkel, J.M. (2011). The evolving regenerative medicine business model: Concept and funding. Harvard Stem Cell Institute. Accessed online September 24, 2012 at http://www.stembook.org/node/713

Porter M. (1990). The Competitive Advantage of Nations. Harvard Press: Cambridge MA.

Porter, M.E. (1998). Competitive Advantage: Creating and Sustaining Superior Performance. Free press.

Powell, W.W., Koput, K.W. \& Smith-Doerr, L. (1996). Interorganizational collaboration and the 
locus of innovation: Networks of learning in biotechnology. Administrative Science Quarterly, 41(1): 116-145.

Resnik, D. (2002). Commercialization of human stem cells: Ethical and policy issues. Health Care Analysis, 10: 127-154.

Rockoff, J. \& Tam, P.W. (2012). "Biotech funding gets harder to find." Wall Street Journal, March 16, 2012. Accessed online on 17-September 2012 at http://online.wsj.com/article/SB10001424052970203961204577267814201399918.html.

Rothaermel, F.T. \& Thursby, M. (2005). Incubator firm failure or graduation?: The role of university linkages. Research Policy, 34(7): 1076-1090.

Scott, C. \& Huggett, B. (2012). Geron's quixotic fate. Nature Biotechnology, 30: 497

Siegel, D.S. \& Phan, P.H. (2005). Analyzing the effectiveness of university technology transfer: Implications for entrepreneurship education. Advances in the Study of Entrepreneurship, Innovation \& Economic Growth, 16: 1-38.

Siegel, D.S., Veugelers, R. \& Wright, M. (2007). Technology transfer offices and commercialization of university intellectual property: Performance and policy implications. Oxford Review of Economic Policy, 23(4): 640-660.

Siegel, D.S., Waldman, D.A., Atwater, L.E. \& Link, A.N. (2004). Toward a model of the effective transfer of scientific knowledge from academicians to practitioners: Qualitative evidence from the commercialization of university technologies. Journal of Engineering and Technology Management, 21(1-2):115-142.

Speser, P.L. (2006). The Art and Science of Technology Transfer. John Wiley \& Sons: Hoboken, New Jersey.

Stam, E. (2015). Entrepreneurial ecosystems and regional policy: A sympathetic critique. European Planning Studies, 23(9): 1759-1769.

Stevenson, H.H. \& Jarillo, J.C. (1990). A paradigm of entrepreneurship: Entrepreneurial management. Strategic Management Journal, 11(5): 17-27.

Taylor, L. (2012). Stem cell market growth "facing thorny challenges." PharmaTimes online, June 18, 2012. Accessed on 17-September 20012 at http://www.pharmatimes.com/article/12- 
06-18/Stem_cell_market_growth_facing_thorny_challenges.aspx.

Tripsas M. (1997). Unravelling the process of creative destruction: Complementary assets and incumbent survival in the typesetter industry. Strategic Management Journal, 18 (S1): 119142.

Trounson, A., Thakar, R.G., Lomax, G. \& Gibbons, D. (2011). Clinical trials for stem cell therapies. BMC Medicine, 2011, 9:52.

U.S. Code (1980). Title 35, Part 2, Chapter 18. Accessed online at http://uscode.house.gov/download/pls/35C18.txt.

Van Looy, B., Callaert, J. \& Debackere, K. (2006). Publication and patent behavior of academic researchers: Conflicting, reinforcing or merely co-existing? Research Policy, 35 (4): 596-608.

WARF (2012). Wisconsin Alumni Research Foundation website. Accessed at http://www.warf.org/news/index.jsp?cid=20

WiCell (2012). WiCell website accessed at http://www.wicell.org/home/about-wicell/aboutwicell.cmsx on 1-November 2012.

Willemstein, L., van der Valk, T. \& Meeus, M.T.H. (2007). Dynamics in business models: An empirical analysis of medical biotechnology firms in the Netherlands. Technovation, 27(4): 221-232.

Wolfinger, N.H., Mason, M.A. \& Goulden, M. (2009). Stay in the game: Gender, family formation and alternative trajectories in the academic life course. Social Forces, 87(3): 15911621.

Zucker, L.G. \& Darby, M.R. (1996). Star scientists and institutional transformation: Patterns of invention and innovation in the formation of the biotechnology industry. Proceedings of the National Academy of Sciences, 93(23): 12709-12716.

Teece, D.J. (2010). Business models, business strategy and innovation. Long range planning, 43(2-3), 172-194.

Zott, C., Amit, R. \& Massa, L. (2011). The business model: Recent developments and future research. Journal of Management, 37(4), 1019-1042. 


\section{Tables and Figures}

Table 1: An integrated typology of regenerative medicine business models

\begin{tabular}{|c|c|c|}
\hline $\begin{array}{l}\text { Business model } \\
\text { structure }\end{array}$ & $\begin{array}{c}\text { Regenerative Medicine } \\
\text { business model categories }\end{array}$ & $\begin{array}{l}\text { Regenerative Medicine } \\
\text { business model elements }\end{array}$ \\
\hline \multirow{8}{*}{ Resources } & \multirow{3}{*}{ Cell model } & Autologous \\
\hline & & Allogenic \\
\hline & & Acellular \\
\hline & \multirow[t]{3}{*}{ Vertical integration } & Niche product \\
\hline & & Platform technology \\
\hline & & Vertically integrated \\
\hline & \multirow[t]{2}{*}{ Resource differentiator } & Research innovation \\
\hline & & Operational efficiency \\
\hline \multirow{9}{*}{ Transaction } & \multirow[t]{2}{*}{ Customer type } & End-user \\
\hline & & Therapeutic developer \\
\hline & \multirow[t]{4}{*}{ Manufacturing specificity } & Industrial scale \\
\hline & & Moderate scale \\
\hline & & Small or batch scale \\
\hline & & Customer scale \\
\hline & \multirow{3}{*}{ Distribution scale } & Local \\
\hline & & Regional/National \\
\hline & & Global \\
\hline \multirow{5}{*}{ Value } & \multirow[t]{3}{*}{ Value form } & Product \\
\hline & & Service \\
\hline & & Solution \\
\hline & \multirow[t]{2}{*}{ Value type } & Profit \\
\hline & & Impact \\
\hline
\end{tabular}


Table 2: Possible business models for Cellular Logistics

\begin{tabular}{|l|l|l|l|}
\hline $\begin{array}{l}\text { Business model } \\
\text { categories }\end{array}$ & $\begin{array}{l}\text { ECM cardiac } \\
\text { therapeutic }\end{array}$ & $\begin{array}{l}\text { ECM cell delivery } \\
\text { platform - in-license }\end{array}$ & $\begin{array}{l}\text { ECM cell delivery } \\
\text { platform - tool sales }\end{array}$ \\
\hline Cell model & Acellular & Acellular & Acellular \\
\hline Vertical integration & Niche & Vertically integrated & Platform \\
\hline $\begin{array}{l}\text { Resource } \\
\text { differentiator }\end{array}$ & $\begin{array}{l}\text { Research } \\
\text { innovation }\end{array}$ & Research innovation & $\begin{array}{l}\text { Operational } \\
\text { efficiency }\end{array}$ \\
\hline Customer type & End-user & End-user & $\begin{array}{l}\text { Therapeutic } \\
\text { developer }\end{array}$ \\
\hline $\begin{array}{l}\text { Manufacturing } \\
\text { specificity }\end{array}$ & Moderate scale & Moderate scale & Industrial scale \\
\hline Distribution scale & Regional / National & Regional / National & Global \\
\hline Value form & Product & Product & Solution \\
\hline Value type & Profit & Profit & Profit \\
\hline
\end{tabular}

ECM = Extracellular Matrix

Table 3: Evolution of Censo Biotechnologies business model

\begin{tabular}{|l|l|l|}
\hline $\begin{array}{l}\text { Business model } \\
\text { categories }\end{array}$ & Focused stem cell sourcing & $\begin{array}{l}\text { Hybrid Regenerative Medicine } \\
\text { product and services provider }\end{array}$ \\
\hline Cell model & Allogenic & Allogenic \\
\hline Vertical integration & Niche product & Vertically integrated \\
\hline Resource differentiator & Research innovation & $\begin{array}{l}\text { Research innovation and } \\
\text { operational efficiency }\end{array}$ \\
\hline Customer type & Therapeutic developer & Therapeutic developer \\
\hline Manufacturing specificity & Customer scale & Small and customer scale \\
\hline Distribution scale & Regional (Europe) & Regional (Europe) and Global \\
\hline Value form & Product and Service & Product, Service and Solution \\
\hline Value type & Not-for-profit & For-profit and impact \\
\hline
\end{tabular}


Table 4: Realized and unrealized business model innovation at Cellular Dynamics

\begin{tabular}{|l|l|l|l|}
\hline $\begin{array}{c}\text { Business model } \\
\text { categories }\end{array}$ & $\begin{array}{l}\text { Original parallel } \\
\text { stem-cell entities } \\
\text { business model }\end{array}$ & $\begin{array}{l}\text { Unrealized parallel } \\
\text { iPS entities business } \\
\text { model }\end{array}$ & $\begin{array}{c}\text { Realized iPS } \\
\text { platform business } \\
\text { model }\end{array}$ \\
\hline Cell model & Allogenic & Allogenic & Allogenic \\
\hline Vertical integration & Niche product & Niche product & Platform technology \\
\hline $\begin{array}{l}\text { Resource } \\
\text { differentiator }\end{array}$ & $\begin{array}{l}\text { Research innovation } \\
\text { and operational } \\
\text { fficiency }\end{array}$ & $\begin{array}{l}\text { Research innovation } \\
\text { and operational } \\
\text { efficiency }\end{array}$ & $\begin{array}{l}\text { Operational } \\
\text { efficiency }\end{array}$ \\
\hline Customer type & $\begin{array}{l}\text { End user and } \\
\text { herapeutic } \\
\text { developer }\end{array}$ & End user and & $\begin{array}{l}\text { Therapeutic } \\
\text { therapeutic }\end{array}$ \\
\hline $\begin{array}{l}\text { developer } \\
\text { sanufacturing }\end{array}$ & $\begin{array}{l}\text { Moderate and batch } \\
\text { scale }\end{array}$ & $\begin{array}{l}\text { Moderate and batch } \\
\text { scale }\end{array}$ & Industrial scale \\
\hline Distribution scale & Global & Global & Global \\
\hline Value form & Product & Product & Solution \\
\hline Value type & Profit & Profit & Profit \\
\hline
\end{tabular}

iPS = Induced Pluripotent Stem Cells 
Figure 1: Entrepreneurial Ecosystem Types (Originally published in Bock and Johnson 2015, European Business Review)

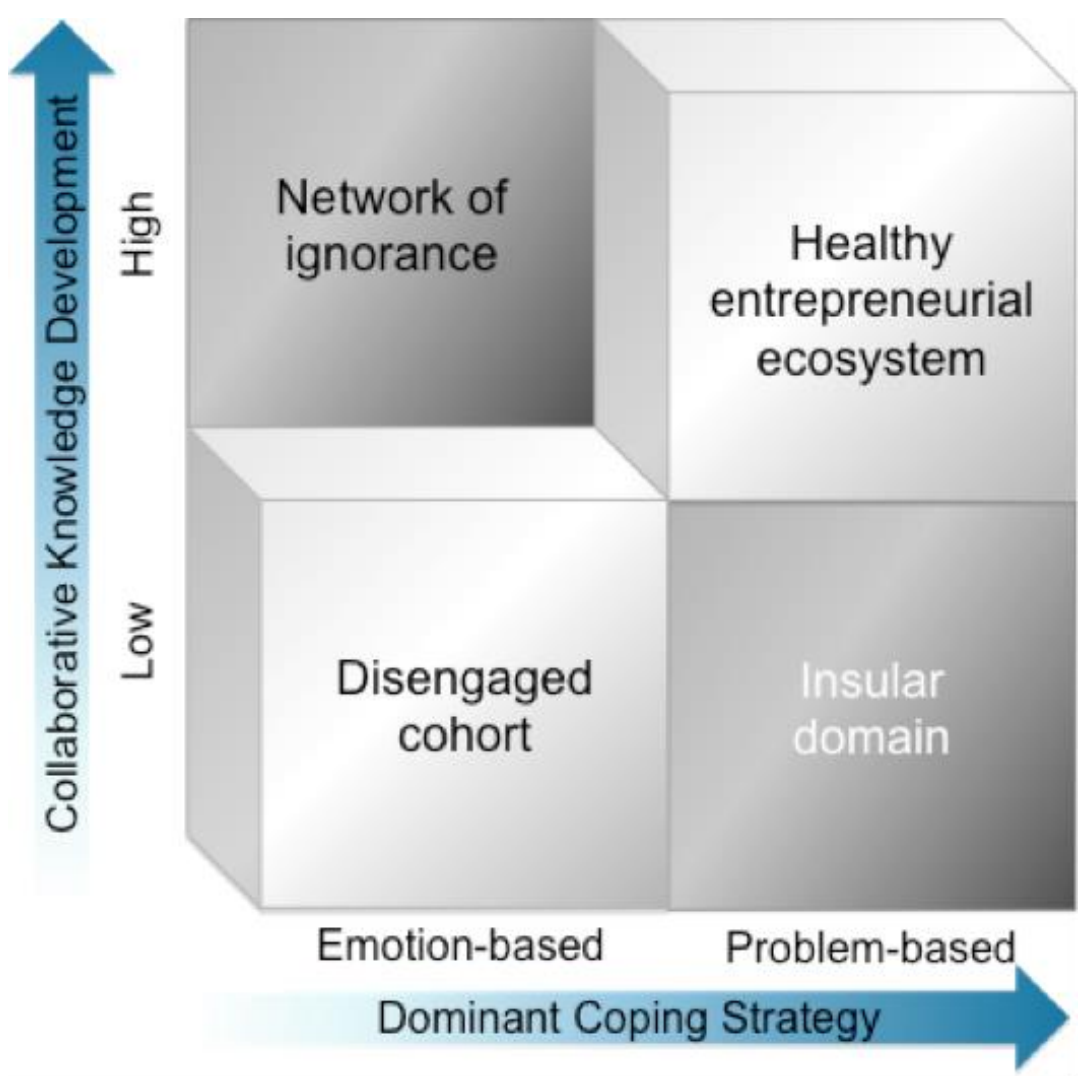

